\title{
Bill may double funds for NIH bone research
}

Funding for osteoporosis research at the National Institutes of Health (NIH) may increase by $\$ 50$ million-a $50 \%$ increase on estimates of current spending-if a bill introduced into the House of Representatives by Congresswoman Eddie Bernice Johnson (Dem.-Dallas), becomes law. The bill also calls for the $\mathrm{NIH}$ to "reinstitute a broader program of Specialized Centers of Research (SCORs) on osteoporosis," and proposes an additional \$3 million for this program which would fund up to three extramural centers.

Johnson's request was one of four osteoporosis bills presented to the House by separate Congresswomen. Collectively referred to as the "Osteoporosis and Related Bone Diseases Research Act of 1997," or

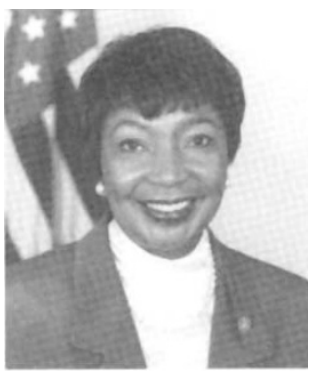

Eddie Bernice Johnson that she requested a large amount because "it's time for these diseases to get the attention they deserve." She added that "until recently, the majority of male members in the House has meant that women's ailments have gone unnoticed."

Bente Cooney, director of public policy at the NOF, applauds the request for more funding. She also revealed that a Department of Defense (DOD) scientific review panel met last week to examine 88 research proposais that were received in response to a $\$ 10$ million Congress award in early spring, 1996. This time to review is an improvement on the 17 months it took the DOD to distribute their first funding for osteoporosis research (\$5 million), which was held up while the military decided why it should H.R.2697, the bills aim to expand health and education programs and improve access to and reimbursement for diagnostic tests for the disease. They have been picked up by Senator Bob Toricelli (Dem.-New Jersey), for simultaneous introduction to the Senate.

Johnson-a registered nurse who describes herself as pre-osteoporotic-was advised on how much money to ask for by groups such as the National Osteoporosis Foundation (NOF) and the Society for Advancement of Women's Health Research. She told Nature Medicine research osteoporosis at all. Cooney points out that the DOD receives $\$ 165$ million for breast cancer research.

Johnson's bill focuses attention on SCORs at a time when their role in osteoporosis research is limited. Despite applications from 11 centers to become osteoporosis SCORs when the program was reviewed this summer, program director Julia Freeman told Nature Medicine that only one center-that run by Henry Kronenberg at Massachusetts General Hospital-was awarded grant money.
Since so many centers failed to make the grade, it is questionable whether the extra funding requested in Johnson's bill would actually be put to immediate use.

In addition to conducting basic and clinical research into osteoporosis, the bill specifies that SCORs develop education programs and training protocols for physicians, scientists and other health professionals and that they disseminate information to such professionals and the public. This represents an expanded function of SCORs' current duties.

The bill states that an estimated 28 million Americans suffer from osteoporosis, with direct medical costs of $\$ 13,800$ million per annum, and it predicts a rise in these costs as the percentage of elderly people in the population increases. The bill comes at a time when the means by which the NIH allocates funding is coming under intense scrutiny: House speaker Newt Gingrich recently announced that he is to create a panel to evaulate whether research into diseases that affect a large percentage of the population are being adequately funded by the NIH.

Johnson is now rallying support for the bill and aims to recruit at least $100 \mathrm{bi}$ partisan sponsors from the House-a minimum 30 out of the 435 members is required-before presenting the document to the Labor/Health and Human Services/Education Appropriations subcommittee for FY99 review.

KAREN BIRMINGHAM

\section{New biomedicine degree for European universities}

European universities may soon be able to offer a new degree course in biomedicine if they follow the lead of the Karolinska Institute in Sweden and the Debrecen University Medical School in Hungary. In addition to teaching traditional biochemistry, physiology and pharmacology, the course specializes in cell and molecular biology, biostatistcs and, in particular, clinically oriented basic research.

Program coordinator Balazs Gulyas, of the Nobel Institute of Neurophysiology at the Karolinska, says that the majority of the Karolinska graduates have found employment within the pharmaceutical industry. Gulyas has 0.5 million ECU $(\sim \$ 650,000)$ from the European Community to develop a similar medical biology curriculum for other EU countries. Pharmaceutical companies from Sweden (Astra and Pharmacia \& UpJohn), and Hungary (Richter and Chinoin-Sanofi) are also supporting the program.

According to Gulyas, a new course is needed because "many medical faculties have realized that the classical medical curriculum is not satisfactory any more for the medical or biomedical industry. We will need biomedical experts who can cover environmental health medicine, medical biotechnology, image processing, CRA's, analytical experts for clinical trials and so on."

Gulyas, a native Hungarian, was instrumental in setting up a course based on the Karolinska model at Debrecen University. Enrollment of 40-45 students will begin in academic year 1998. Gulyas told Nature Medicine that a similar course will be started at an Italian university in 1999.

Eleven European universities, including Edinburgh, Montpelier, Berlin, Gothenberg, Uppsala and Lund, are said to be considering introducing such a course. The first symposium aimed at evaluating the program was held at the Karolinska Institute in midNovember.

KAREN BIRMINGHAM 